\title{
PENGARUH BEBERAPA PERLAKUAN TERHADAP PENGURANGAN KADAR FORMALIN PADA IKAN YANG DITENTUKAN SECARA SPEKTROFOTOMETRI
}

\author{
Yulizar Yusuf, Zamzibar Zuki, MP dan Ruci Riski Amanda \\ Laboratorium Kimia Analitik Terapan Jurusan Kimia FMIPA Universitas Andalas \\ Jurusan Kimia FMIPA Unand, Kampus Limau Manis, 25163 \\ Email: yulizaryusuf59@gmail.com
}

\begin{abstract}
The case of how handling the fresh fish which used the dangerous chemical material (formaldehyde) is still found in society, so that is why it is necesarry to find the safety way to handle the fresh fish in. It has been held the research about the influence of on the effect of some treatment in reduction the formaldehyde level on fish determined by spectrophotometry UV-Visible at wavelength $412 \mathrm{~nm}$ and $40^{\circ} \mathrm{C}$. In the preliminary research the fish is soaked in formaldehyde liquid $(100 \mathrm{mg} / \mathrm{mL})$ for 24 hours, then washed, soaked and boiled. Then, the filtrate is reacted with Nash reagent. The yellow color which has formed was measured at $\lambda 412$ $\mathrm{nm}$. The result shows there is the reduction of formaldehyde level in the sample about $43.9 \%$ after washing, 33.3 \% after soaking, 53.8 \% after boiling. After that, the fish that was spread in the market which suspected containing the formaldehyde then washed, soaked and boiled. The result shows there is the reduction of formalin level in sample 1 about $22,7 \%$ after washing, $17.0 \%$ after soaking, and $96.1 \%$ after boiling. While in sample 2, $41.8 \%$ after washing, $56.2 \%$ after soaking, and $95.4 \%$ after boiling.
\end{abstract}

Keywords: Formaldehyde, fresh fish, Nash reagent, UV-Vis spectrophotometry

\section{PENDAHULUAN}

Ikan merupakan salah satu bahan pangan yang sering dikonsumsi masyarakat dan kaya akan protein, lemak, vitamin dan mineral yang sangat baik. Disisi lain, ikan termasuk jenis bahan pangan yang mudah rusak (membusuk) karena tingginya kadar protein dan kadar air menyebabkan mudah ditumbuhi mikroba, sehingga ikan tidak mampu bertahan lebih lama. Hanya beberapa jam saja sejak ditangkap dan didaratkan akan timbul proses perubahan yang mengarah pada kerusakan $^{[1]}$.

Cara yang umum dilakukan untuk mencegah kerusakan yaitu pengawetan dengan menggunakan es balok. Kendala yang dihadapi bila menggunakan es balok adalah dibutuhkan jumlah yang cukup banyak sehingga tidak praktis dan harganya mahal. Hal tersebut menyebabkan nelayan dan penjual yang curang menggunakan zat kimia yang berbahaya seperti formalin sebagai pengganti es balok karena harga formalin jauh lebih murah dan dapat mengawetkan ikan dalam jangka waktu yang lama, namun penggunaan formalin sangat berbahaya bahkan dalam dosis yang sedikit tetapi penggunaannya yang berkelanjutan dapat menimbulkan dampak negatif bagi kesehatan masyaraka $^{[2]}$. Dengan memperhatikan permasalahan di atas, perlu ada upaya yang harus dilakukan untuk menjamin bahan makanan yang akan dikonsumsi aman dari bahaya formalin. Salah satu upaya dengan melakukan beberapa perlakuan terhadap ikan sebelum dikomsumsi, yaitu dengan cara pencucian, perendaman, dan perebusan.

Penelitian terdahulu yang telah dilakukan oleh Levita, J dkk (2010) yaitu pengaruh perendaman, pencucian dan penggorengan terhadap kosentrasi formaldehid dalam ikan asin sange belah. Ikan asin tersebut direndam dalam larutan formalin $(250 \mathrm{mg} / \mathrm{l})$ selama 12 jam, kemudian dicuci, digoreng. Destilat direaksikan dengan pereaksi Nash. Warna kuning yang terbentuk diukur pada $\lambda$ 
$415 \mathrm{~nm}$. Hasil yang diperoleh dari penelitian menunjukkan bahwa terdapat penurunan kosentrasi formaldehid dalam sampel setelah diberi perlakuan $(63,27 \%$ setelah perendaman dan pencucian, $83,03 \%$ setelah penggorengan) ${ }^{[3]}$.

Metode analisis formalin dapat dilakukan secara kualitatif dan kuantitatif. Analisis kualitatif formalin biasanya berdasarkan pada reaksi warna, sedangkan analisis kuantitatif dilakukan dengan menggunakan beberapa metode, yaitu dengan titrasi volumetri, spektrofotometri, kromatografi gas dan kromatografi cair kinerja tinggi. Metode kromatografi gas dan kromatografi cair kinerja tinggi memiliki sensitivitas dan selektivitas yang sangat baik. Namun, analisis secara kromtografi gas dan kromatografi cair kinerja tinggi memerlukan instrumentasi yang relatif mahal dan rumit. Selain itu, dibutuhkan proses derivatisasi menggunakan zat penderivat yang mahal. Oleh karena itu, pada penelitian ini digunakan metode analisis kuantitatif yang lebih sederhana dan sensitif, yaitu spektrofotometri. Pada metode spektrofotometri dibutuhkan pereaksi, dimana pereaksi yang sering digunakan yaitu pereaksi asam kromatofat, pereaksi Nash dan pereaksi Schryver. Pada penelitian ini dipilih pereaksi Nash karena memiliki sensitivitas dan selektivitas yang cukup baik dan sudah di validasi $^{[4]}$.

Penelitian ini bertujuan untuk melihat apakah ada pengaruh pencucian, perendaman dan perebusan terhadap penurunan kandungan formalin pada ikan.

\section{METODOLOGI PENELITIAN}

\section{Bahan Kimia}

Bahan yang digunakan pada penelitian ini adalah Formalin pa mengandung $37 \%$ formaldehid dalam air, Ammonium asetat (Merck), Asam asetat glasial pa, asetil aseton pa, ikan, akuades.

\section{Peralatan}

Peralatan yang digunakan dalam penelitian ini adalah labu ukur, gelas ukur, gelas piala, erlenmeyer, termometer, tabung reaksi, kaca arloji, spatula besi, neraca analitik, lumpang, alu, aluminium foil, kertas saring, masker, pipet volumetri, Spektrofotometer UV-Vis.

\section{Prosedur Penelitian}

\section{Pembuatan Pereaksi Nash}

Sebanyak $2 \mathrm{~mL}$ asetil aseton, $3 \mathrm{~mL}$ asam asetat dan $150 \mathrm{~g}$ ammonium asetat dilarutkan dengan akuades dan dicukupkan volumenya hingga $1 \mathrm{~L}$.

\section{Pembuatan Larutan Standar 1000 mg/L}

Larutan formalin $37 \%$ diambil $0,25 \mathrm{~mL}$ diencerkan dengan akuades dalam labu 100 $\mathrm{mL}$, kemudian dilarutkan dengan pengenceran bertingkat untuk mendapatkan konsentrasi yang kita inginan.

\section{Persiapan Sampel}

Sampel yang digunakan adalah ikan yang dibeli dari Pasar Raya Padang. Ikan yang sudah dibeli kemudian dicuci dengan aquadest dan disaring, kemudian direndam selama 24 jam dalam larutan formalin 100 $\mu \mathrm{g} / \mathrm{mL}$ dengan volume tertentu. Sampel yang berformalin tersebut di berikan beberapa perlakuan diantaranya tanpa perlakuan, dicuci, direndam dan direbus. Sampel dicuci dengan akuades sebanyak $250 \mathrm{~mL}$ dengan 5 kali pengulangan dengan cara dialirkan. Kemudian sampel direndam dengan akuades sebanyak $250 \mathrm{~mL}$ dalam gelas piala selama 30 menit dan sampel direbus dengan akuades sebanyak $250 \mathrm{~mL}$ dalam gelas piala selama 30 menit. Masing-masing dilakukan sebanyak 3 kali pengulangan.

\section{Pengaruh Suhu Terhadap Panjang Gelombang Optimum}

Salah satu konsentrasi standar formalin yaitu $10 \mu \mathrm{g} / \mathrm{mL}$ dipipet $5 \mathrm{~mL}$ dimasukkan kedalam masing-masing labu ukur $25 \mathrm{~mL}$. Ditambahkan $5 \mathrm{~mL}$ akuades dan $5 \mathrm{~mL}$ pereaksi Nash. Masing-masing campuran diperlakukan tanpa pemanasan dan dipanaskan dalam penangas air pada suhu 40 dan $60^{\circ} \mathrm{C}$ selama 30 menit sambil ditutup. Setelah dingin ditepatkan volumenya menggunakan akuades, dikocok hingga homogen. Diamati serapannya pada panjang gelombang $380-490 \mathrm{~nm}$ dengan alat spektrofotometer UV-Vis hingga didapat panjang gelombang maksimum untuk setiap suhu. 


\section{Pembuatan Kurva Kalibrasi}

Larutan formalin dengan konsentrasi $0,2,4$, $6,8,10,12,14 \mu \mathrm{g} / \mathrm{mL}$. Masing-masing larutan standar diambil $5 \mathrm{~mL}$ dimasukkan dalam labu ukur $25 \mathrm{~mL}$ kemudian ditambahkan $5 \mathrm{~mL}$ akuades dan $5 \mathrm{~mL}$ pereaksi Nash lalu dipanaskan dalam penangas air pada suhu optimum selama 30 menit sambil ditutup. Setelah dingin tepatkan volumenya menggunakan akuades, dikocok hingga homogen. Diamati serapannya pada panjang gelombang $412,78 \mathrm{~nm}$ dengan alat spektrofotometer UV-Vis. Kemudian dibuat kurva kalibrasi hingga didapat persamaan liner $\mathrm{y}=\mathrm{a}+\mathrm{bx}$. Lineritas dari kurva kalibrasi dilihat dengan menghitung koefisien korelasi (r) dari persamaan garis regresi linier.

\section{Penentuan Kadar Formalin Pada Sampel}

Sampel ikan diambil daging dibagian badan ikan dan ditimbang sebanyak $10 \mathrm{~g}$ dan ditambah akuades sebanyak $50 \mathrm{~mL}$. Dihaluskan dengan lumpang kemudian disaring dengan kertas saring. Diambil $5 \mathrm{~mL}$ filtrat dimasukkan kedalam labu ukur $25 \mathrm{~mL}$. Ditambahkan akuades sebanyak $5 \mathrm{~mL}$ dan 5 $\mathrm{mL}$ pereaksi Nash lalu dipanaskan kedalam penangas air pada suhu optimum selama 30 menit sambil ditutup, setelah dingin dan ditepatkanvvolumenya menggunakan akuades. Dikocok hingga homogen. Diukur dengan spektrofotometer UV-Vis dengan panjang gelombang $412,78 \mathrm{~nm}$.

\section{Penentuan Persen Perolehan Kembali}

Penentuan perolehan kembali dilakukan dengan menggunakan sampel yang telah diketahui konsentrasinya kemudian dilakukan adisi standar dengan kondisi tertentu. Ditimbang sampel sebanyak $10 \mathrm{~g}$, dihancurkan dengan lumpang kemudian ditambahkan formalin kosentrasi $14 \mu \mathrm{g} / \mathrm{mL}$. Sampel disaring ke dalam labu ukur $50 \mathrm{~mL}$ sambil ditambahkan akuades sebanyak 50 $\mathrm{mL}$. Larutan dipipet sebanyak $5 \mathrm{~mL}$ ke dalam labu $25 \mathrm{~mL}$, ditambahkan $5 \mathrm{~mL}$ reagen Nash dan $5 \mathrm{~mL}$ akuades. Campuran tersebut dipanaskan pada suhu $40{ }^{\circ} \mathrm{C}$ selama 30 menit, didinginkan dan ditepatkan volumenya dengan akuades kemudian diukur serapanya pada panjang gelombang $412,78 \mathrm{~nm}$. Persen perolehan kembali diperoleh dari perbandingan konsentrasi sampel setelah adisi dengan sejumlah konsentrasi standar dan sampel.
$\%$ Perolehan Kembali $=\frac{\mathrm{C} 1-\mathrm{C} 2}{\mathrm{C} 3} \quad 100 \%$

Keterangan :

$\mathrm{C}_{1}=$ Konsentrasi sampel setelah adisi

$\mathrm{C}_{2}=$ Konsentrasi sampel sebelum adisi

$\mathrm{C}_{3}=$ Konsentrasi standar yang ditambahkan

\section{HASIL DAN DISKUSI}

\section{Panjang Gelombang dan Suhu untuk Menghasilkan Absorban Maksimum}

Panjang gelombang maksimum pengukuran yang dilakukan pada larutan formalin pada kosentrasi masing-masing $10 \mu \mathrm{g} / \mathrm{mL}$ yang dilarutkan dengan akuades dan reagen Nash yang memberikan hasil warna kuning menggunakan spektrofotometri UV-Vis pada rentang panjang gelombang $380-490 \mathrm{~nm}$. Menurut literatur, formalin memiliki serapan optimum pada panjang gelombang $412 \mathrm{~nm}$ ${ }^{[10]}$. Setelah dilakukan pengukuran didapatkan panjang gelombang maksimum 412,78 $\mathrm{nm}$. Hasil pengukuran serapan larutan formalin dapat terlihat pada Gambar 1.

Dari hasil pengukuran serapan larutan formalin dilihat bahwa pada panjang gelombang 412,78 nm didapatkan puncak tertinggi dengan nilai absorban yaitu 0,501 pada suhu optimum $40^{\circ} \mathrm{C}$ dalam pelarut air dan penambahan reagen Nash. Pemilihan panjang gelombang maksimum larutan formalin dilakukan agar dapat mengetahui daerah maksimum formalin bekerja memberikan serapan warna yang dapat diabsorbsi oleh alat spektofotometer UV-Vis, sehingga dapat dihasilkan nilai berupa absorbansi. Selain itu pemilihan panjang gelombang maksimum juga berfungsi untuk mengetahui selektifitas dan sensitifitas formalin.

\section{Linearitas dan Kurva kalibrasi}

Uji linieritas dilakukan dengan membuat kurva kalibrasi yang dapat menghasilkan persamaan garis regresi serta nilai koefisien determinasi yaitu untuk mengetahui hubungan antara konsentrasi larutan baku dengan nilai serapan yang dihasilkan. Kurva kalibrasi larutan formalin yang dibuat dari lima konsentrasi larutan formaldehid yaitu 0 , $2,4,6,8,10,12,14 \mu \mathrm{g} / \mathrm{mL}$. Hal ini dapat dilihat pada Gambar 2 . 


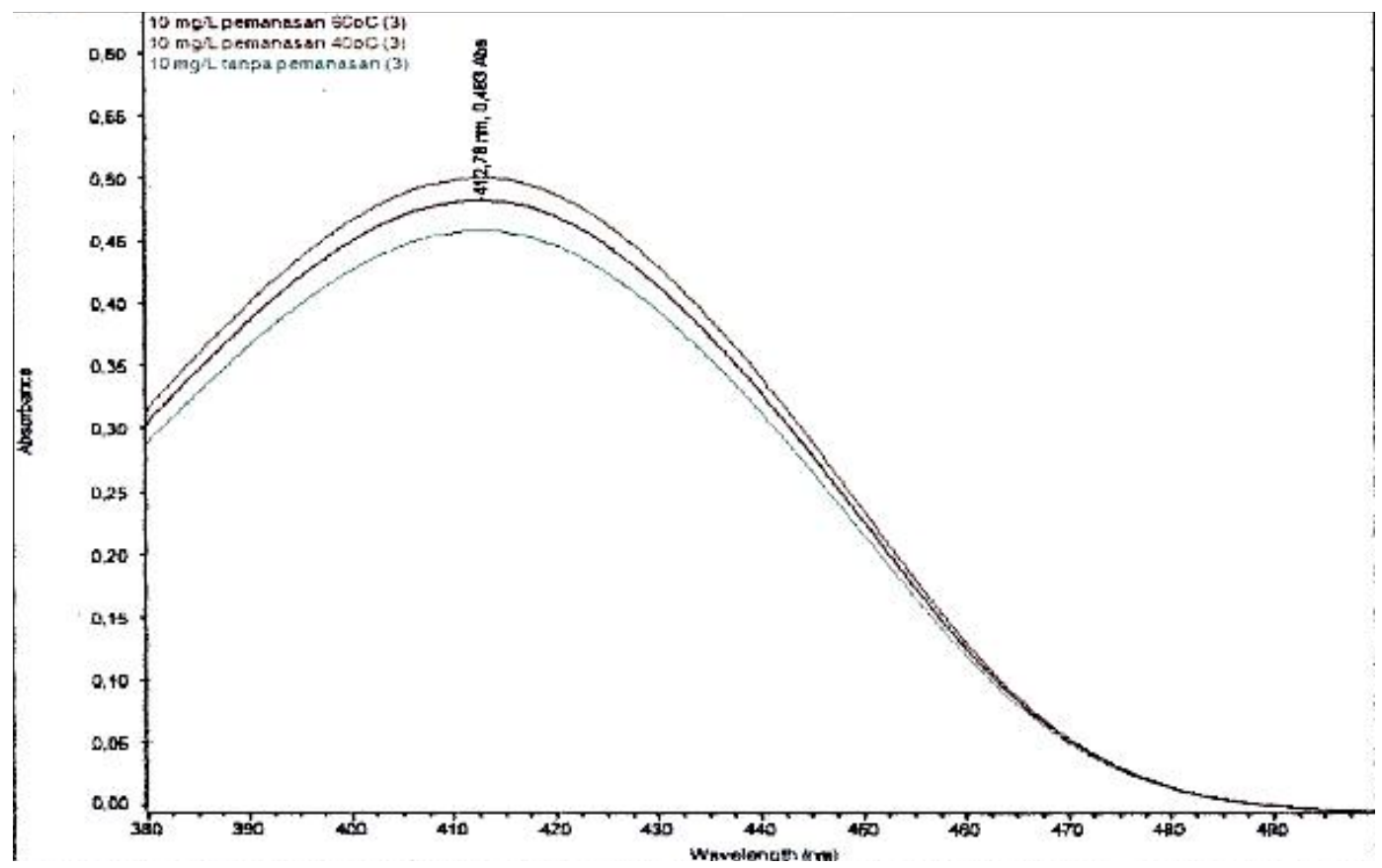

Gambar. 1 Spektrum Serapan Optimum Hasil Reaksi Antara Formalin Kosentrasi $10 \mu \mathrm{g} / \mathrm{mL}$ dengan Reagen Nash pada suhu $27^{\circ} \mathrm{C}, 40^{\circ} \mathrm{C}$ dan suhu $60^{\circ} \mathrm{C}$.

Berdasarkan hasil kurva yang didapatkan menunjukkan bahwa nilai absorbansi yang dihasilkan meningkat dengan peningkatan konsentrasi larutan standar formalin yang dibuat. Hasil pengukuran sederetan larutan standar formalin didapatkan persamaan regresi dari formalin $\mathrm{y}=0,0488 \mathrm{x}-0,0087$ dengan nilai koefisien determinasi $\left(\mathrm{R}^{2}\right)$ 0,999. Nilai koefisien korelasi yang diperoleh menunjukkan hasil yang baik karena mendekati nilai 1 , sehingga dapat dikatakan terdapat hubungan yang erat antara konsentrasi dan nilai absorban yang terukur dimana semua titik dari hasil pengukuran terletak pada satu garis lurus.

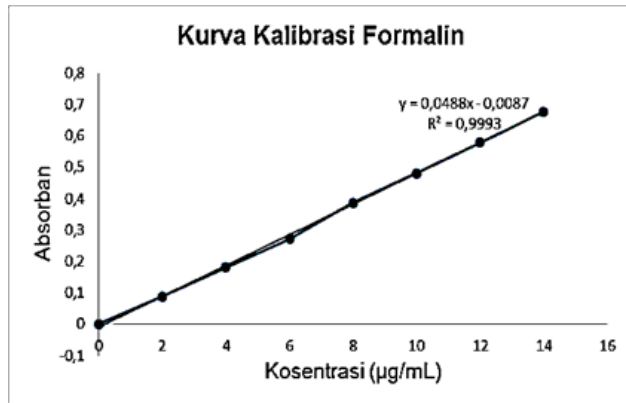

Gambar 2. Kurva Kalibrasi formalin

\subsection{Hasil Pengukuran Batas Deteksi (LoD) dan Batas Kuantisasi (LoQ)}

Penentuan batas deteksi dan batas kuantisasi dari formalin dilakukan dengan pengukuran dari semua larutan standar dengan rentang konsentrasi $2 \mu \mathrm{g} / \mathrm{mL}$ hingga $14 \mu \mathrm{g} / \mathrm{mL}$ dengan pengulangan sebanyak delapan kali. Dari hasil perhitungan diperoleh batas deteksi (LoD) formalin adalah sebesar $0,3569 \mu \mathrm{g} / \mathrm{mL}$ dan batas kuantisasi (LoQ) adalah sebesar $1,1899 \mu \mathrm{g} / \mathrm{mL}$.

\subsection{Uji Kadar Formalin \\ 3.4.1 Pengukuran Kadar Formalin Pada Sampel}

Hasil analisis kadar formalin pada ikan segar yang direndam dalam larutan formalin 100 $\mu \mathrm{g} / \mathrm{mL}$ selama 24 jam, kemudian dicuci, direndam dan direbus dapat dilihat pada Tabel 1. Dari hasil penelitian yang telah dilakukan pada ikan didapatkan kadar formalin sebelum diberi pelakuan sebesar $0,3344 \mu \mathrm{g} / \mathrm{g}$ dan setelah diberi perlakuan terjadi penurunan kadar formalin sebanyak 43,959 \% pada ikan dimana sisa kandungan formalin dalam ikan dengan pencucian sebesar $0,1874 \mu \mathrm{g} / \mathrm{g}$, proses perendaman 
terjadi penurunan kadar formalin sebanyak $33,343 \%$ dimana sisa kandungan formalin dalam ikan sebesar $0,2229 \mu \mathrm{g} / \mathrm{g}$ dan proses perebusan juga terjadi penurunan kadar formalin sebanyak $53,789 \%$ dimana sisa kandungan formalin dalam ikan sebesar $0,1545 \mu \mathrm{g} / \mathrm{g}$.

Hal ini terjadi karena sifat kimia dari formalin yang bisa bereaksi dengan protein dalam ikan, dan membuat daging lebih elastis. Proses pemanasan dapat menghidrolisis protein dan memperlonggar ikatan dengan formalin. Sehingga formalin kemudian dilepaskan sebagai senyawa yang mudah menguap. Kondisi ini disebabkan oleh sifat fisikokimia formalin dimana kelarutannya dalam air dan kecenderungan untuk menguap pada suhu yang lebih tinggi [14]

\subsubsection{Hasil Pengukuran Kadar Formalin Pada Ikan Di Pasaran}

Hasil analisis kadar formalin pada ikan segar yang diperoleh di pasar yang diduga mengandung formalin, diberi perlakuan yaitu dicuci, direndam dan direbus dapat dilihat pada Tabel 2. Dari hasil penelitian didapatkan nilai kadar formalin yang keluar pada sampel yang diperoleh di pasar yaitu pada sampel 1 dibeli di Pasar Raya Padang, didapatkan kadar formalin sebelum perlakuan sebesar $0,2588 \mu \mathrm{g} / \mathrm{g}$ dan setelah proses pencucian dengan air mengalir menurunkan kadar formalin sebanyak $22,720 \%$ dimana sisa kandungan formalin pada sampel sebesar $0,2000 \mu \mathrm{g} / \mathrm{g}$, proses perendaman menurunkan kadar formalin sebanyak $17,040 \%$, dimana sisa kandungan formalin pada sampel sebesar $0,2147 \mu \mathrm{g} / \mathrm{g}$ dan proses perebusan dapat menurunkan kadar formalin sebanyak 96,097\% dimana sisa kandungan formalin yang terkandung pada sampel sebesar 0,0101 $\mu \mathrm{g} / \mathrm{g}$.

Sedangkan pada sampel 2 dibeli di Pasar Ambacang, didapatkan kadar formalin sebelum perlakuan sebesar $0,3247 \mu \mathrm{g} / \mathrm{g}$ setelah proses pencucian dengan air mengalir menurunkan kadar formalin sebanyak $41,823 \%$, dimana sisa kandungan formalin pada sampel sebesar $0,1889 \mu \mathrm{g} / \mathrm{g}$, proses perendaman menurunkan kadar formalin sebanyak $56,239 \%$, dimana sisa kandungan formalin sebesar $0,1418 \mu \mathrm{g} / \mathrm{g}$ dan proses perebusan dapat menurunkan kadar formalin sebanyak 95,442\%, dimana sisa kandungan formalin pada sampel sebesar $0,0148 \mu \mathrm{g} / \mathrm{g}$.

Walaupun sifat formalin cenderung menguap pada suhu tinggi tapi pada proses perebusan tidak menghilangkan semua kandungan formalin pada sampel karena formalin dapat berikatan dengan protein. Hal ini sependapat dengan penelitian Hastuti ${ }^{[8]}$ yang menyatakan bahwa daging yang direndam dalam larutan formalin sebagai pengawet, formalin tersebut mengikat dengan protein serta senyawa lain dan sisanya tetap dalam bentuk formalin bebas yang kemudian akan diserap ke dalam jaringan (daging), sehingga akan terlindungi dari udara luar dan akibatnya sangat lambat terjadi penguapan, sehingga formalin masih terdeteksi dalam sampel.

Dari Tabel 2, ikan yang dijual di pasar Kota Padang masih ada yang menggunakan formalin untuk mengawetkan bahan makanan, padahal berdasarkan peraturan Menteri Kesehatan RI No.1168/MENKES/PER/X/1999 formalin merupakan bahan pengawet yang dilarang untuk pegawetan makanan. Penambahan formalin untuk mengawetkan ikan disebabkan jarak penangkapan dengan lokasi pasar yang jauh serta kapal yang digunakan nelayan masih sangat sederhana. Pengawetan dengan menggunakan batu es memerlukan biaya yang sangat mahal, sehingga nelayan lebih memilih formalin untuk mengawetkan makanan karena biaya lebih murah ${ }^{[2]}$.

Tabel 1. Hasil analisis kadar formalin 100 $\mu \mathrm{g} / \mathrm{mL}$ pada sampel sebelum dan sesudah diberi beberapa perlakuan

\begin{tabular}{|c|c|c|}
\hline Proses & $\begin{array}{c}\text { Kadar } \\
\text { Formalin Pada } \\
\text { Sampel }(\mu \mathrm{g} / \mathrm{g})\end{array}$ & $\begin{array}{c}\text { Penurunan } \\
\text { Kadar Formalin } \\
(\%)\end{array}$ \\
\hline$(\mathrm{A})$ & 0,3344 & - \\
\hline$\left(\mathrm{B}_{1}\right)$ & 0,1874 & 43,959 \\
\hline$\left(\mathrm{B}_{2}\right)$ & 0,2229 & 33,343 \\
\hline$\left(\mathrm{B}_{3}\right)$ & 0,1545 & 53,798 \\
\hline
\end{tabular}

Keterangan :
(A) = Sampel tanpa perlakuan
$\left(B_{1}\right)=$ Sampel dicuci dengan air mengalir
$\left(B_{2}\right)=$ Sampel direndam selama 30 menit
$\left(B_{3}\right)=$ Sampel direbus selama 30 menit 
Tabel 2. Hasil analisis kadar formalin pada sampel yang diperoleh di pasar sebelum dan sesudah diberi beberapa perlakuan

\begin{tabular}{|c|c|c|c|}
\hline \multirow{2}{*}{ Sampel } & Proses & $\begin{array}{c}\text { Kadar } \\
\text { Formalin } \\
\text { pada } \\
\text { Sampel } \\
(\mu \mathrm{g} / \mathrm{g})\end{array}$ & $\begin{array}{c}\text { Penurunan } \\
\text { kadar formalin } \\
(\%)\end{array}$ \\
\hline \multirow{4}{*}{1} & $(\mathrm{~A})$ & 0,2588 & - \\
\cline { 2 - 4 } & $\left(\mathrm{B}_{1}\right)$ & 0,2000 & 22.720 \\
\cline { 2 - 4 } & $\left(\mathrm{B}_{2}\right)$ & 0,2147 & 17,040 \\
\cline { 2 - 4 } & $\left(\mathrm{B}_{3}\right)$ & 0,0101 & 96,097 \\
\hline \multirow{4}{*}{2} & $(\mathrm{~A})$ & 0,3247 & - \\
\cline { 2 - 4 } & $\left(\mathrm{B}_{1}\right)$ & 0,1889 & 41,823 \\
\cline { 2 - 4 } & $\left(\mathrm{B}_{2}\right)$ & 0,1418 & 56,329 \\
\cline { 2 - 4 } & $\left(\mathrm{B}_{3}\right)$ & 0,0148 & 95,442 \\
\hline
\end{tabular}

\section{Hasil Pengukuran Perolehan Kembali (\%)}

Penentuan perolehan kembali bertujuan untuk mengetahui tingkat ketepatan suatu metode yang dilakukan dengan cara membandingkan konsentrasi sampel setelah adisi dengan konsentrasi standar dan sampel. Persen perolehan kembali dilakukan dengan menambah sejumlah larutan standar dalam sampel tertentu. Nilai perolehan kembali yang mendekati $100 \%$ menunjukkan tingkat kesesuaian dari rata-rata suatu pengukuran yang sebanding dengan nilai sebenarnya. Dari hasil percobaan didapatkan perolehan kembali pada sampel ikan yang ditambahkan formalin dengan kosentrasi $14 \mu \mathrm{g} / \mathrm{mL}$ yaitu $96,84 \%$. Hasil uji perolehan kembali yang memenuhi syarat adalah $93 \%$ - $99 \%$. Dengan demikian, dapat dikatakan bahwa metode ini memiliki ketepatan yang cukup baik.

\section{KESIMPULAN}

Dari hasil penelitian yang telah dilakukan menunjukkan bahwa pengukuran kadar formalin pada sampel yang direndam larutan formalin $100 \mu \mathrm{g} / \mathrm{mL}$ terjadi penurunan kadar formalin setelah diberi perlakuan yaitu $43 \%$ pada proses pencucian dengan air mengalir, proses perendaman terjadi penurunan kadar formalin sebanyak $33 \%$ dan proses perebusan juga terjadi penurunan kadar formalin sebanyak $53 \%$.

Pengukuran kadar formalin pada sampel yang diperoleh dipasaran terjadi penurunan kadar formalin yaitu pada sampel 1, proses pencucian dengan air mengalir menurunkan kadar formalin sebanyak $22 \%$, proses perendaman menurunkan kadar formalin sebanyak $17 \%$, dan proses perebusan dapat menurunkan kadar formalin sebanyak $96 \%$. Sedangkan pada sampel 2, proses pencucian dengan air mengalir menurunkan kadar formalin sebanyak $41 \%$, proses perendaman menurunkan kadar formalin sebanyak $56 \%$, dan proses perebusan dapat menurunkan kadar formalin sebanyak $95 \%$.

\section{UCAPAN TERIMA KASIH}

Ucapan terima kasih penulis sampaikan kepada analis-analis Laboratorium Jurusan Kimia yang turut membantu selama penelitian.

\section{DAFTAR PUSTAKA/ REEFRENCES}

1. Tunhun, Dusadee, Sombat K., Mayuree C. and Nongnuch R., 2008, Detection of Ilegal Addition of Formaldehyde to Fresh Fish, Faculty of Fisheries, Kasetsart University, Bangkok.

2. Adawyah R., 2007, Pengolahan dan Pengawetan Ikan, Bumi Aksara, Jakarta.

3. Levita J., Musfiroh I., Indriyati W., and Mustarichie R., 2010, The Effect of Soaking, Washing and Frying on The Concentration of Formaldehyde in Sange Belah Salty Fish, Jurnal Ilmu-Ilmu Hayati dan Fisik, 1, 12.

4. Aswad M., Fatmawaty A., Nursamsiar, dan Rahmawanti, 2011, Validasi Metode spektrofotometri sinar Tampak untuk Analisis Formalin Dalam Tahu. Majalah Farmasi dan Farmakologi, 1, 15, 26-29. 
5. Cahyadi W., 2006, Analisis dan Aspek Kesehatan Bahan Tambahan Pangan, Bumi Aksara, Jakarta.

6. Li J., Zhu J., Ye L., 2007, Determination of Formaldehyde in Squid by High-Performance Liquid Chromatography, Asia Pacific Journal, 16, 127-130.

7. Aprilianti, Ayudiah, Ma'ruf A., Fajarini Z. N., Purwanti D., 2007, Studi Kasus Penggunaan Formalin Pada Tahu Takwa Di Kotamadya Kediri, PKM Penulisan Ilmiah (PKMI), Program Kreativitas Mahasiswa, Universitas Muhammadiyah Malang, Malang.

8. Hastuti S., 2010, Analisis Kualitatif dan Kuantitatif Formaldehid pada Ikan Asin di Madura, Agrointek, 2, 4.

9. Mardiana, 2009, Pengaruh Perendaman dengan Air Mendidih dan Dingin Terhadap Kadar Formalin dalam Ayam Kemasan yang di Jual di Beberapa Supermarket di Kota Medan, Skripsi, Jurusan Kimia, Fakultas MIPA, USU, Medan.

10. Departemen Kesehatan Republik Indonesia. 1979. Farmakope

11. Schyver, S.B., 1910, The Photochemical Formation of Formaldehyde in Green Plants, Proc. Roy. Soc. London, Series B 82, 554, 227.

12. Nash, T., 1953, Colorimetric estimation of Formaldehyde By
Means of Hantzch Reaction, Biochem, J, 55, 3, 417-418.

13. Susanti S., 2010, Penetapan Kadar Formaldehid Pada Tahu yang Dijual di Pasar Ciputat Dengan Metoda Spektrofotometri UV-Vis Disertai Kolometri Menggunakan Pereaksi Nash. Skripsi, Fakultas Kedokteran dan Ilmu Kesehatan, Universitas Muslim Negeri, Jakarta.

14. Harmita, 2004, Petunjuk Pelaksanaan Metode Validasi dan Cara Perhitungannya, Jurnal Ilmu Kefarmasian, 3, 1, 117-121.

15. Wu P., Chang C., and Chou S., 2003, Determination of Formaldehyde Incosmetics by HPLC Method and Acetyl Acetone Method. Journal of Food and Drug Analysis, 1, 1, 8-15.

16. Fessenden, R.J., dan Fesseden, J.S., 1997, Buku Terjemahan, Dasar Dasar Kimia Organik, alih bahasa : Maun S., Anas K., Sally T.A, Binarupa Aksara, Jakarta, 361.

17. Lehotay J. and Hromulakova K., 1994, HPLC Determination of Trace Levels ofAaliphaticAldehydes C1-C4 in River and Tap Water Using Online Preconcentration. Journal Liquid Chromatography, 3, 17, 579.

18. Cahyadi W., 2006, Kajian dan Analilis Bahan Tambahan Pangan. Edisi Pertama, Pustaka Sinar Harapan, Jakarta. 